\title{
Oxidative stability of lard and sunflower oil supplemented with coffee extracts under storage conditions
}

\author{
By Grażyna Budryn, ${ }^{*}$ Ewa Nebesny and Dorota Żyżelewicz
}

\author{
Department of Chemical Food Technology, Faculty of Biotechnology and Food Sciences, \\ Technical University of Lodz, Stefanowskiego 4/10, 90-924 Lodz, Poland
}

( ${ }^{\star}$ Corresponding author: grazyna.budryn @p.lodz.pl)

\section{RESUMEN}

Estabilidad oxidativa de manteca y aceite de girasol suplementados con extractos de café bajo condiciones de almacenamiento.

La estabilidad oxidativa de manteca y aceite de girasol suplementados con extractos acuosos de granos de café verde o tostado Arábica y Robusta fue estimada. Un descenso en la velocidad de las reacciones de oxidación de la grasa durante el almacenamiento de las muestras durante 12 semana a temperatura ambiente, que resulto de la adición de los extractos de café, fue evaluada usando métodos químicos estándares tales como la determinación de peróxidos y el índice de paranisidina y ensayos de dienos y trienos conjugados, así como métodos físicos tales como la determinación del perfil térmico por DSC. También las propiedades sensoriales de todas las grasas fueron estimadas. Estas medidas mostraron que extractos acuosos de café al $0.1 \%$ en la grasa decrecieron $(p<0.05)$ los valores obtenidos por los métodos químicos con respecto al control y aproximadamente redujo a la mitad la velocidad de oxidación. También el análisis del perfil térmico revelo que la suplementación con extractos de café redujo la extensión de cambios negativos en las propiedades de las grasas. La efectividad de los extractos de café ensayados decrecieron en el orden: Robusta verde $>$ Arábica verde $>$ Robusta tostado $>$ Arábica tostado.

PALABRAS-CLAVE: Aceite de girasol - Estabilidad oxidativa - DSC - Extractos de café - Manteca.

\section{SUMMARY}

Oxidative stability of lard and sunflower oil supplemented with coffee extracts under storage conditions.

The oxidative stability of sunflower oil and lard supplemented with water extracts of green and roasted, Arabica and Robusta coffee beans was estimated. A decrease in the rate of fat oxidation reactions during the storage of samples for 12 weeks at ambient temperature which resulted from the addition of coffee extracts was evaluated using standard chemical methods such as the determination of peroxide and $p$-anisidine value and the assays of conjugated dienes and trienes as well as physical methods such as the determination of thermal profile by DSC. The sensory properties of all fat samples were also determined. These measurements showed that $0.1 \%$ water coffee extracts in fats decreased $(p<0.05)$ the quantities assayed by the chemical methods as compared to the control samples and approximately halved the rate of fat oxidation. In addition, the thermal profile analysis revealed that supplementing with coffee extracts reduced the extent of negative changes in the thermal properties of fats. The effectiveness of the tested coffee extracts decreased in the order: green Robusta > green Arabica > roasted Robusta > roasted Arabica.

KEY-WORDS: Coffee extracts - DSC - Lard - Oxidative stability - Sunflower oil.

\section{INTRODUCTION}

The majority of oils and edible fats are chemically unstable, in particular when exposed to oxygen and light which bring about oxidation even under standard storage conditions. The oxidation of fats not only gives rise to an unpleasant smell and taste but also generates potentially harmful or toxic compounds (Luzia et al., 1997). The consumption of oxidized lipids leads to the formation of reactive forms of oxygen and free radicals which in turn oxidize biological membranes and display potential mutagenic, genotoxic and angiotoxic activities. They also contribute to the development of cardiovascular system disorders, faster ageing processes, a loss in vitamins, mainly tocopherols, and act as inhibitors of enzymes (Sikwese and Duodu, 2007). Oxidation not only decreases the stability of oils and fats during long term storage but also negatively affects the stability of lipid containing foods, in particular those which were thermally processed like fried foodstuffs (Anwar et al., 2006). To some extent these disadvantageous processes taking place during the storage of fats can be slowed down through supplementation with antioxidants. The most frequently applied, synthetic antioxidants pose a threat to human health and therefore natural antioxidants have attracted attention. The occurrence of many natural antioxidants in raw materials, mainly of plant origin, has been well documented (Bandoniene et al., 2000). Up to now, the most promising results come from investigations of extracts from rosemary and sage that stabilized oils used in frying (Irwandi et al., 2000). Potentially rich sources of antioxidants are also such plants like rice, garlic, grapes, green tea, and coffee (Renuka Devi et al., 2007, lqbal and Bhanger, 2007). Previously, roasted 
coffee was added to foods as an antioxidant, as it is usually consumed after roasting (Nissen et al., 2004). However, green coffee contains much more (even 10-fold) polyphenols than roasted coffee (Budryn et al., 2009). Anwar et al. (2006) investigated the effects of sunflower oil supplementing with methanolic green coffee extracts. However, chlorogenic acids that are responsible for the antioxidant activity of green coffee beans are more soluble in water than in alcohols. Besides, water is nontoxic and therefore aqueous coffee bean extracts should also be used in studies on the oxidative stability of fats. Various reactions taking place during fat storage can be monitored by using diverse analytical methods enabling the determination of polar compounds and free fatty acid contents along with iodine, peroxide and $p$-anisidine values. However, these methods are time and labor consuming, and usually require the application of toxic reagents (Tan and Che Man, 1999a). Therefore they are frequently replaced by instrumental methods including spectrophotometric ones and the differential scanning calorimetry (DSC) (Gloria and Aguilera, 1998). The latter are well correlated with the results of chemical methods. The highest correlation was observed between the results of DSC and polar compound assays (Tan and Che Man, 1999b).

The objective of this work was to determine the effect of the aqueous extracts of green and roasted coffee beans on the long term oxidative stability of lard and sunflower oil as representative edible fats. The analyses were carried out using standard and instrumental methods.

\section{MATERIALS AND METHODS}

\subsection{Materials}

The tested materials were pork lard from a local market and sunflower oil purchased from "Kruszwica" ZPT (Poland). They were supplemented with dried water extracts from green and roasted Robusta coffee beans (Coffea canephora), which were grown in Indonesia and processed by the dry method as well as from green and roasted Arabica coffee beans (Coffea arabica), from Columbia, processed by the wet method. Green Robusta and Arabica beans were purchased from Aspol Ltd. (Poland).

\subsection{Coffee bean roasting}

Both types of coffee beans were roasted in a laboratory, convective coffee roaster with an automatic cooler, Precission Heartware (USA), until a $17 \%$ decrease in their weight was achieved (a difference in weight before and after roasting per $100 \mathrm{~g}$ coffee beans (Daglia et al., 2000). The temperature inside the roasting chamber was measured using a NiCr-NiAl thermocouple (Poland). In the last stage of roasting it reached 240 and $235^{\circ} \mathrm{C}$ for Robusta and Arabica (roasting duration of 12 and $9.5 \mathrm{~min}$ ), respectively. The humidity of coffee beans was determined by drying at $103^{\circ} \mathrm{C}$ until constant weight (Lakenbrink, 2000). It was 0.8 and $1.1 \%$ for Robusta and Arabica, respectively. The color of green and roasted coffee beans was measured according to the CIE $L^{*} a^{*} b^{*}$ system (Lopez-Galilea et al., 2006) using a Specord M-40 spectrophotometer, Carl-Zeiss Jena (Germany). Changes in color parameters caused by the roasting of Robusta coffee beans were as follows: $L^{*}$ decreased from 70.33 to 42.65 , $a^{*}$ increased from 2.83 to $5.34, b^{*}$ decreased from 21.57 to 20.66. The changes for Arabica coffee beans were similar: $L^{*}$ : decreased from 75.51 to 41.84 , a*: increased from 1.68 to $4.68, b^{*}$ : decreased from 20.28 to 19.47. Green coffee beans were ground in a laboratory mill WZ-1, ZBPP (Poland), which was adapted to the grinding of very hard beans. The roasted coffee beans were ground in a II Macinino F.A.C.E.M Spa - Tre Spade mill (Italy). The dimensions of the ground particles (suspended in paraffin oil) were measured using a micrometric screw NSK Digitrix Mark II Electronic Micrometer, Japan Micrometer MFG.CO.LTD (Japan). Their dimensions ranged from 480 to $680 \mu \mathrm{m}$.

\subsection{Preparing of coffee extracts}

Extracts from ground, green and roasted, Arabica and Robusta coffee beans were prepared at a coffee: water ratio of 1:5.75, which ensured approximately $5 \%$ solid concentration, that was optimal for extract lyophilization. The extracts were obtained through boiling in water at $110^{\circ} \mathrm{C}$ for 10 min in a pressure cooker PS-5682 First (Austria). Rapid cooling and filtration under reduced pressure were carried out in a vacuum pump KNF Neuberger N 035.3 AT.18 (Germany). After that, the extracts were freeze-dried in a DELTA 1-24LSC Christ lyophilizer (Germany) to prevent deterioration of the preparations and to limit the addition of water to the fat samples (Shishikura et al., 2006). The solid substance content in the extracts was assayed through drying at $103^{\circ} \mathrm{C}$. It was $1.3,2.5,1.0$ and $2.8 \%$ for extracts from green and roasted Robusta and green and roasted Arabica, respectively. The concentrations of chlorogenic acids (determined by HPLC) were $37.6,3.74,19.56$ and $6.19 \%$ of dried extracts and the $\mathrm{pH}$ values of solutions prepared by dissolving $2 \mathrm{~g}$ of dry extract in water to $100 \mathrm{~mL}$ volume measured with a Schott CG Schott Geräte $\mathrm{GmbH}$ pH-meter (Germany) were 6.0, 5.3, 5.9 and 5.1 , respectively.

\subsection{Preparation of fat samples supplemented with coffee bean extracts}

The concentration of the lyophilized coffee extracts added to lard and sunflower oil was $0.1 \%$. This concentration was selected based on the results of earlier studies aimed at compromising between the antioxidant effect and sensory properties. After the addition of coffee extracts to sunflower oil 
samples, mixtures were stirred for 10 min with a magnetic stirrer to achieve a uniform distribution of the antioxidants. Samples of lard were blended with coffee extracts at room temperature using a blender (in a manner preventing excessive aeration). Fat samples (30 g each) were kept in the dark at $20^{\circ} \mathrm{C}$ in open dishes with a diameter of $18 \mathrm{~cm}$ (exposed to air oxygen).

\subsection{Analysis of fats}

The extent of oxidative changes during storage was estimated based on changes in iodine, peroxide and $p$-anisidine values, indexes of conjugated dienes and trienes contents (according to standard methods) as well as on changes in the thermal profile as evaluated by DSC. The thermal analysis enabling estimation of the intensity of oxidative changes in fats during their storage was conducted using a DSC 111 (Setaram, France). Fat melting was carried out in the temperature range of 20 and $60^{\circ} \mathrm{C}$ for lard and -55 and $5^{\circ} \mathrm{C}$ for sunflower oil. Lard and sunflower oil samples were cooled starting from an ambient temperature until complete solidification and were kept for $5 \mathrm{~min}$ at temperatures of 20 and $-55^{\circ} \mathrm{C}$, respectively. The heating rate was $3^{\circ} \mathrm{C} \times \min ^{-1}$. Results of the thermal analysis were processed using the scanning calorimeter software. Melting temperature was determined based on peaks on melting curves and the enthalpy of phase transition was computed based on the surface area under peaks I and II and on a sample mass basis. Calibration of temperature and energy was carried out using the indium standard and the same scanning rate as for tested samples.

Evaluation of the sensory properties of fats was carried out by 5 well trained panelists having sufficiently high sensory sensitivity and knowledge related to the evaluated properties. Results were described in a 5-point intensity scale in which 1 corresponded to extremely unaccepted, changed and indicating oxidative deterioration features while 5 corresponded to typical, characteristic and well accepted properties. The taste, aroma and color of fats were evaluated according to this scale and the overall score was a mean of these 3 partial scores.

All evaluations were carried out in triplicate. Their results were subjected to variance analysis (ANOVA) and the Duncan test (DMRT). Statistical significance of the results was determined at $p<0.05$.

\section{RESULTS AND DISCUSSION}

\subsection{Oxidative stability evaluated by chemical methods}

Detection of the initial products of fatty acid oxidation is of particular importance during investigations of long term storage at ambient temperature when comparing to high temperature conditions, where these substances are quickly destroyed. Fig. 1 shows changes in peroxide value
(PV) during the storage of lard and sunflower oil supplemented with extracts from green and roasted, Robusta and Arabica coffee beans. After 12 weeks of storage the PV of lard without coffee antioxidants (control) was more than 15 times higher than the initial PV $\left(0.6\right.$ meq $\left.\mathrm{O}_{2} \times \mathrm{kg}^{-1}\right)$ and reached $10.6 \mathrm{meq} \mathrm{O}_{2} \times \mathrm{kg}^{-1}$ (Fig. 1a). The significant differences $(p<0.05)$ in PV between the control and samples supplemented with coffee extracts were observed. Extracts from both types of green coffee considerably slowed down $(p<0.05)$ the growth of PV starting from the third week of storage and after 12 weeks PV values were only approximately twice that of the fresh material (1.1 and 1.3 meq $\mathrm{O}_{2} \times \mathrm{kg}^{-1}$ for extracts from green Robusta and Arabica, respectively). The positive effect of extracts from roasted Robusta and Arabica coffee beans on PV was observed $(p<0.05)$ from the sixth week of storage (as compared to the control) and values of PV increased by 10 times (up to 5.1 and 5.9 meq $\mathrm{O}_{2} \times \mathrm{kg}^{-1}$ for roasted Robusta and Arabica, respectively).

The initial PV of sunflower oil was $2.7 \mathrm{meq}$ $\mathrm{O}_{2} \times \mathrm{kg}^{-1}$ and after a 12 week storage period it increased approximately 25-fold (to 67.2 meq $\mathrm{O}_{2} \times$ $\mathrm{kg}^{-1}$ ) in the control free from coffee extracts (Fig. $1 \mathrm{~b})$. It is a consequence of the fatty acid profile of sunflower oil which usually contains approximately $90 \%$ unsaturated fatty acids while lard only contains $50 \%$ (mainly monounsaturated). The rate of
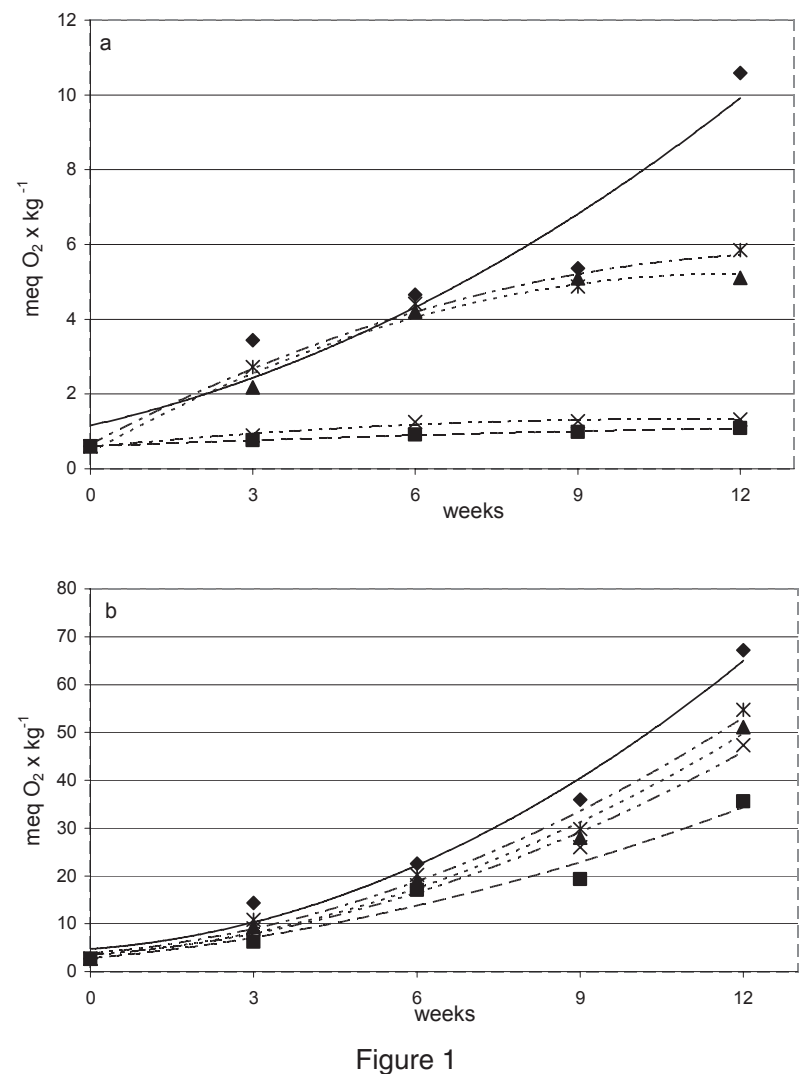

Peroxide value of a) lard and b) sunflower oil stored for 12 weeks at $20{ }^{\circ} \mathrm{C}, \bullet$ - control and $\mathbf{- G R}, \times-\mathrm{GA}, \boldsymbol{\Delta}-\mathrm{RR}$ and $*$ - RA - with addition of green Robusta, green Arabica, roasted Robusta and roasted Arabica respectively. 
peroxide formation was reduced by supplementing with coffee extracts $(p<0.05)$. The best results were observed for green Robusta extracts because after 12 weeks PV increased only 13-fold (to 35.6 meq $\mathrm{O}_{2} \times \mathrm{kg}^{-1}$ ) thus two times less than for the control. The other examined coffee extracts were less efficient and after 12 weeks $\mathrm{PV}$ reached approximately 50 meq $\mathrm{O}_{2} \times \mathrm{kg}^{-1}$. Results reported by other authors indicate that only extracts from plants with high antioxidant activity cause a similar (2-fold) slowing down of peroxide formation in oils with the comparable level of unsaturated fatty acids (Anwar et al., 2006). The same effect was observed for the pure preparation of 5-caffeoylquinic acid which is one of the components of coffee extracts (Luzia et al., 1997).

Also the $p$-anisidine value (AV), which reveals the presence of secondary fatty acid oxidation products, was different for the 2 tested fats both before and after 12 weeks of storage experiment (Fig. 2a and b). Under drastic storage conditions the concentration of these secondary products can be very high (Guillen and Cabo, 2002). Supplementing with coffee extracts significantly decreased AV in both fats ( $p<0.05)$. This effect was stronger for lard samples because their AV was almost constant with an exception of the samples enriched with the roasted Arabica extract. Despite the growth of AV in the latter, the ultimate values were almost 5 times lower than in the control. For the sunflower oil samples the lowest AV was found
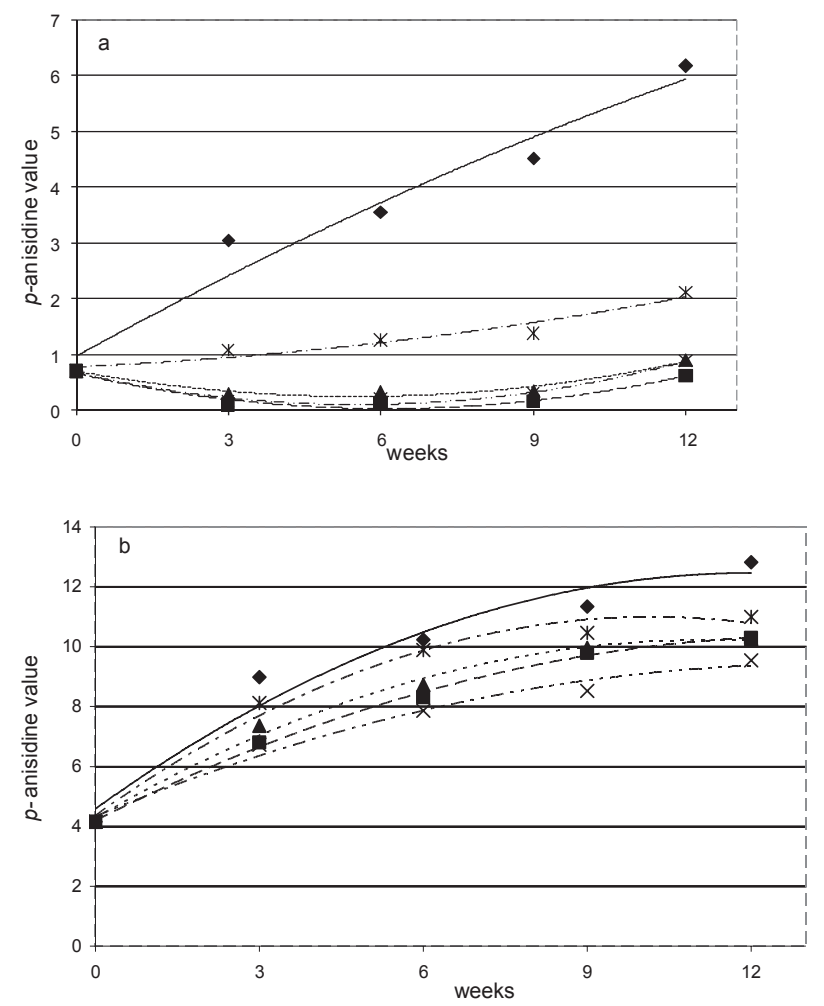

Figure 2

$P$-anisidine value of a) lard and b) sunflower oil stored for 12 weeks at $20{ }^{\circ} \mathrm{C}, \bullet$ - control and - GR, $\times$ - GA, $\boldsymbol{\Delta}$ - RR and $*$ - RA - with addition of green Robusta, green Arabica, roasted Robusta and roasted Arabica respectively. for those supplemented with green Arabica extract (the efficiency close to $30 \%$ ).

The conjugated dienes index (CD) also reflects the concentration of fatty acid hydroperoxides. The initial CD value of lard was small (0.06, Fig. $3 a)$ and in the control it increased to 0.45 after 12 weeks of storage while in samples supplemented
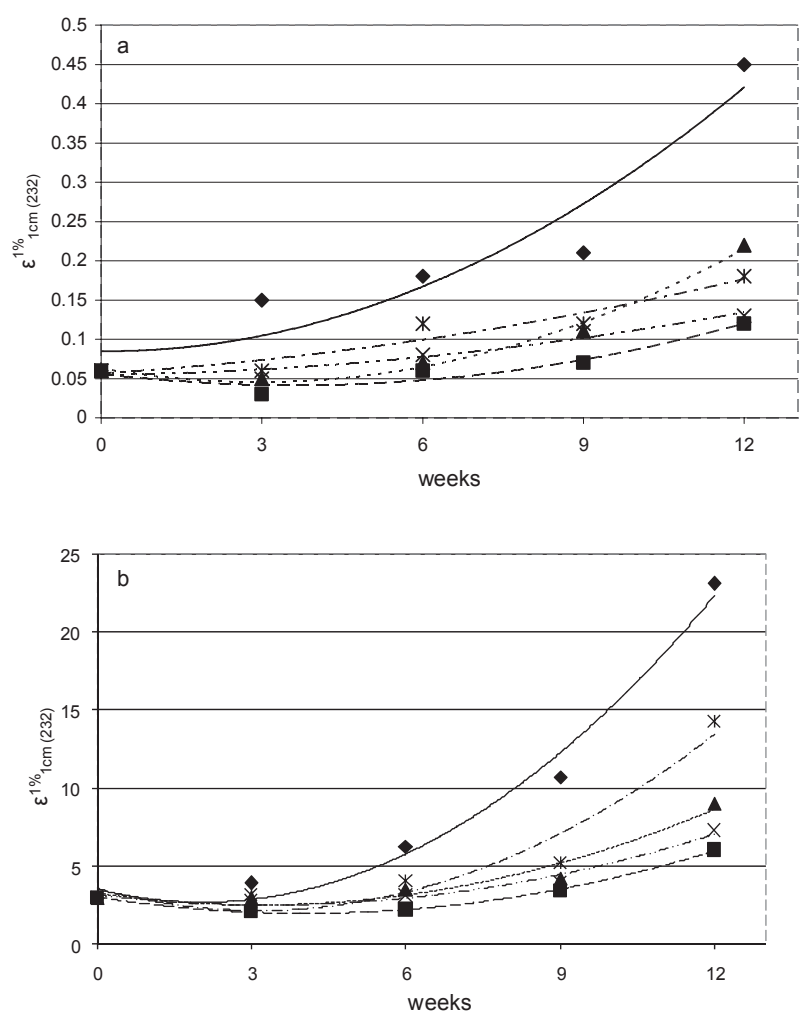

Figure 3

Conjugated dienes index in a) lard and b) sunflower oil stored for 12 weeks at $20^{\circ} \mathrm{C},-$ control and $\mathbf{\square}-\mathrm{GR}, \times-\mathrm{GA}, \boldsymbol{\Delta}-\mathrm{RR}$ and $*$ - RA - with the addition of green Robusta, green Arabica, roasted Robusta and roasted Arabica respectively.

with coffee extracts it increased to only 0.12 and 0.13 for Robusta and Arabica, respectively. During the 12 week incubation of the control sample of sunflower oil its CD grew from 3.0 to 23.1 (Fig. 3b) while in samples supplemented with coffee extracts this growth was slower, in particular for samples supplemented with extracts from green coffee beans (CD approaching 6.0 and 14.3 for green Robusta and roasted Arabica, respectively). Thus the most active extract from green Robusta 3-fold reduced the $C D$ value of both lard and sunflower oil kept for 12 weeks as compared to the respective control.

Other authors observed the same slower rise in $C D$ when fats were supplemented with antioxidants (similar as for PV) (Anwar et al., 2006). The discrepancy between our results (the stronger positive effect of our coffee extracts) and their findings can result from differences in the initial fat quality (Albi et al., 1997). When the initial value of $\mathrm{CD}$ is relatively high, its increase during storage can be smaller as compared to that of very fresh and high quality fats. For samples of pure linoleic acid with high analytical quality the increase in CD 
was 10 times lower when it was supplemented with either roasted coffee extract or rosemary extract which acted as highly effective antioxidants (Schwarz et al., 2001).

Also the increase in the concentration of conjugated trienes (CT), shown in Fig. 4, is a marker of oxidative deterioration of fat. A rise in CT was the lowest for extracts from green Robusta and Arabica coffee beans as compared to the control and samples enriched with the roasted coffee extracts, although the CT of the latter was significantly lower as compared to the control ( $p<$ 0.05 ) after a 12 week incubation of the fats. So this result was also consistent with the above results related to the PV and CD. Values of CT were higher for the sunflower oil samples than for the lard samples because of the known difference in fatty acid profiles. In samples supplemented with green and roasted coffee extracts the increase in CT was observed from the ninth and the sixth weeks of storing, respectively, while in the control - after the third week $(p<0.05)$. After 12 weeks of storage the value of $C T$ was approximately 2 times higher for the control than for the sample supplemented with green Robusta extract.

Anwar et al. (2006) found that among various methanol plant extracts, those from coffee displayed the highest protective activity. But reduction in the increase in the CT of sunflower oil caused by these methanol coffee extracts was almost two times lower compared to the aqueous extracts used in the presented study.

\subsection{Sensorial analysis}

At $0.1 \%$ concentration the extracts did not cause any significant changes in sensory properties of
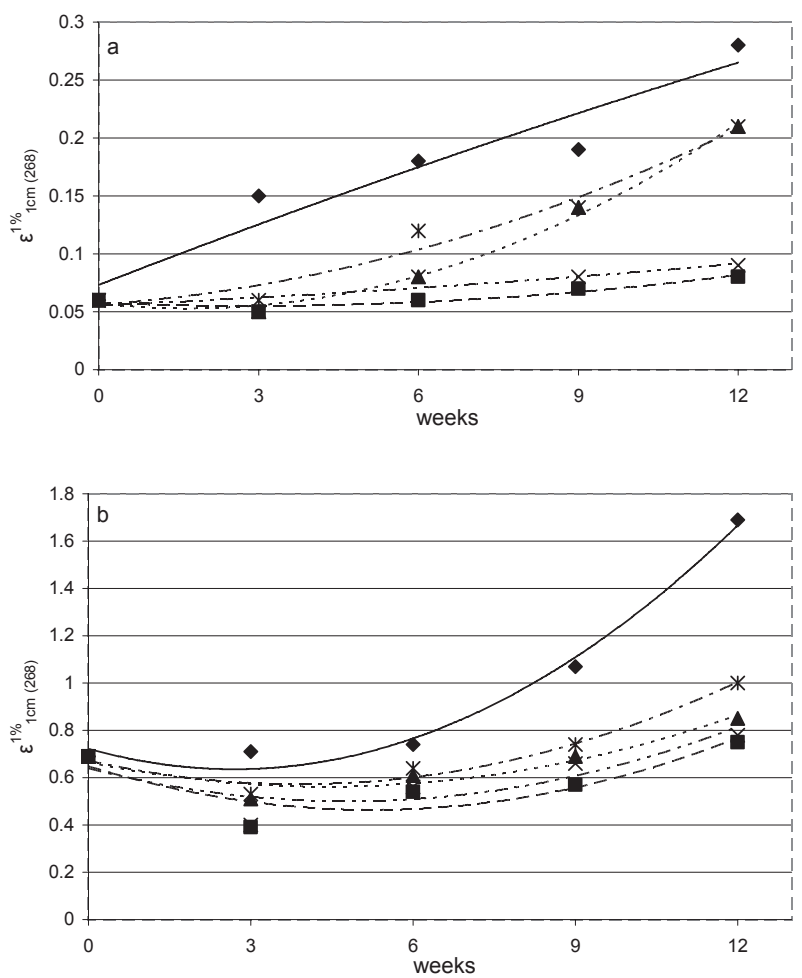

Figure 4

Conjugated trienes index in a) lard and $b$ ) sunflower oil stored for 12 weeks at $20^{\circ} \mathrm{C}, \bullet$ - control and $\mathbf{\square}-\mathrm{GR}, \times$ - GA, $\boldsymbol{\Delta}$ - RR and $*$ - RA - with addition of green Robusta, green Arabica, roasted Robusta and roasted Arabica respectively.

both the fats and prior to the storage experiment their samples received the highest scores (5) (Table 1). After 12 weeks of storage, the sensory properties of the fats were worse, in particular for the samples of sunflower oil which was more

Table 1

Changes in thermal and organoleptic properties of sunflower oil and lard supplemented with coffee extracts during storage

\begin{tabular}{|c|c|c|c|c|c|c|}
\hline \multicolumn{2}{|c|}{ Sample } & $\begin{array}{c}\text { Storage } \\
\text { time } \\
\text { (weeks) }\end{array}$ & $\begin{array}{l}\text { Melting } \\
\text { enthalpy } \\
(\mathrm{J} / \mathrm{g})\end{array}$ & $\begin{array}{c}\text { Melting I peak } \\
\text { temperature } \\
\left({ }^{\circ} \mathrm{C}\right)\end{array}$ & $\begin{array}{c}\text { Melting II peak } \\
\text { temperature } \\
\left({ }^{\circ} \mathrm{C}\right)\end{array}$ & $\begin{array}{c}\text { Organo-leptic } \\
\text { properties }\end{array}$ \\
\hline \multirow{2}{*}{\multicolumn{2}{|c|}{ Control }} & 0 & 44.36 & $34.22^{a}$ & $49.94^{a}$ & $5.0^{c}$ \\
\hline & & 12 & 29.75 & $35.28^{b}$ & $52.91^{\mathrm{b}}$ & 4.0 \\
\hline \multirow{4}{*}{ Lard } & Green Robusta & 12 & $40.04^{a}$ & 33.21 & $49.59^{a}$ & $4.5^{\mathrm{a}}$ \\
\hline & Green Arabica & 12 & $40.15^{a}$ & $34.30^{\mathrm{a}}$ & $49.92^{\mathrm{a}}$ & $4.5^{\mathrm{a}}$ \\
\hline & Roasted Robusta & 12 & $38.03^{a}$ & $34.66^{a, b}$ & $49.68^{\mathrm{a}}$ & $4.5^{\mathrm{a}}$ \\
\hline & Roasted Arabica & 12 & 33.48 & $35.45^{\mathrm{b}}$ & $52.84^{\mathrm{b}}$ & $4.4^{\mathrm{a}}$ \\
\hline \multirow{6}{*}{ Sunflower oil } & \multirow{2}{*}{ Control } & 0 & 121.91 & $-28.13^{d}$ & $-21.71^{c}$ & $5.0^{c}$ \\
\hline & & 12 & 88.72 & $-29.50^{c}$ & $-20.94^{d}$ & 3.1 \\
\hline & Green Robusta & 12 & $115.67^{c}$ & $-28.18^{d}$ & $-21,68^{c}$ & $3.6^{b}$ \\
\hline & Green Arabica & 12 & $113.54^{c}$ & $-28.59^{d}$ & $-21.43^{c}$ & $3.5^{\mathrm{b}}$ \\
\hline & Roasted Robusta & 12 & $99.97^{\mathrm{b}}$ & $-29.12^{c}$ & $-20.91^{d}$ & $3.4^{\mathrm{b}}$ \\
\hline & Roasted Arabica & 12 & $97.43^{b}$ & $-29.10^{c}$ & $-20.86^{d}$ & $3.4^{\mathrm{b}}$ \\
\hline
\end{tabular}

Values in each line bearing the same letters are not significantly different $(p>0.05)$. 
susceptible to oxidation. The scores for the lard and sunflower oil samples supplemented with the coffee extracts were by approximately 0.5 higher than for their respective controls. On completion of the storage experiment the best sensory properties were displayed in the samples supplemented with green Robusta extracts.

\subsection{Changes in thermal properties}

Thermal analysis provides information of the temperature and enthalpy of melting of either whole fat or its fractions (when their melting temperatures are different). These curves are characteristic for individual fats and their originality can be identified by this method (Calligaris et al. 2008; Chiavaro et al., 2007; Campos et al., 2002). Melting temperature is usually decreased by fat heating or storage as compared to the fresh fat because of the appearance of triacylglycerol degradation products which decrease the order of molecules in the crystal lattice (Vittadini et al. 2006; Tan et al., 2002). Also some changes in individual fat fractions can take place which gives rise to the appearance of additional peaks, the dividing of broad initial peaks to multiple narrow peaks and the shifting of some peaks to higher temperature values (Besbes et al., 2005). Thus changes in thermal profiles are multidirectional and the degree of fat deterioration can be estimated based on discrepancies between the profile of fresh fat and the examined one. The heating of fat always decreases melting enthalpy because of disturbances in the fat crystal lattice caused by the presence of products of fat degradation (Besbes et al., 2005). A thermal analysis of lard and sunflower oil samples revealed 2 peaks, a larger and a smaller one (the latter at the higher melting temperature). The other smaller peaks were not analyzed. The values of melting enthalpy were determined throughout the melting process (Table 1, Fig. 5). The greater deviations from the initial peaks and the greater decrease in the enthalpy were ascribed to more advanced changes in fat composition caused by oxidative degradation. After 12 week storage the greatest changes in thermal profiles were observed for both controls whereas the thermal profiles of the samples supplemented with coffee extracts, in particular from green Robusta and Arabica, were less affected. A decrease in the melting enthalpy of the lard control and samples supplemented with green Robusta and Arabica extracts was 33 and $10 \%$, respectively. For sunflower oil samples these values were lower, at 27,5 and $7 \%$, respectively.

\section{CONCLUSIONS}

Our results prove that water extracts from coffee beans, in particular from green Robusta, approximately halved the rate of fatty acid oxidation. This effect is comparable to the effects observed for other plant antioxidants. These
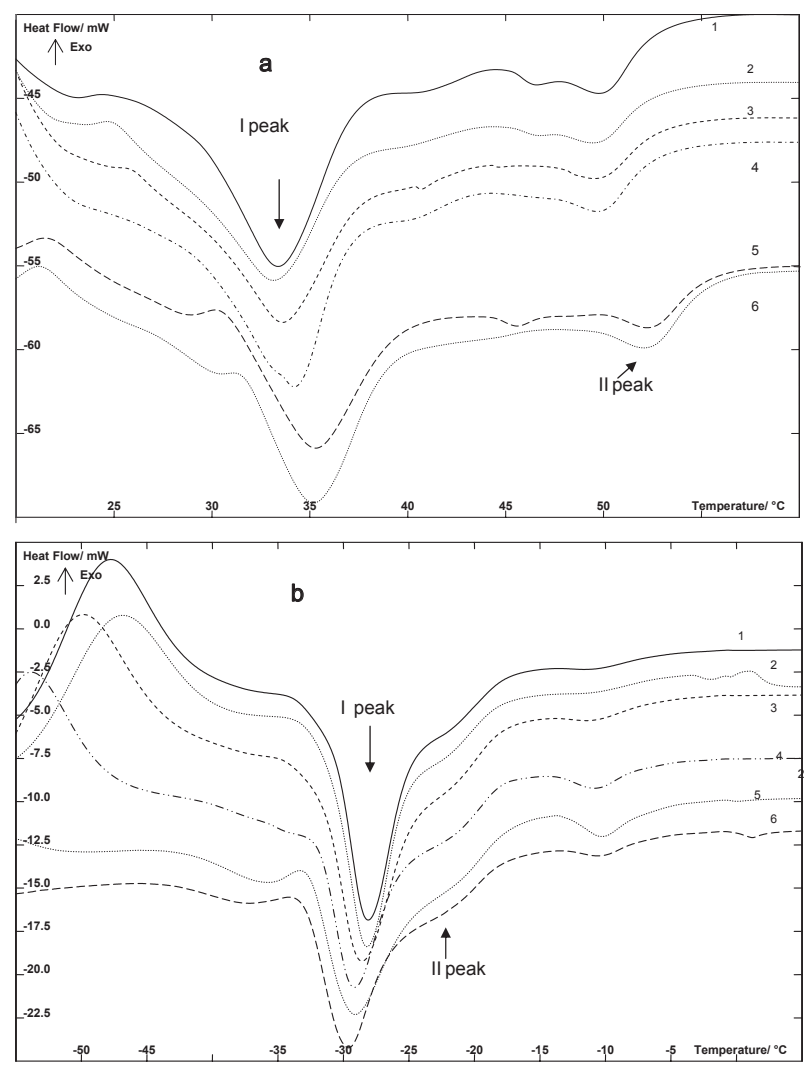

Figure 5

Thermograms of the melting of a) lard and b) sunflower oil kept for 12 weeks at $20^{\circ} \mathrm{C}, 1-$ fresh, 2 - supplemented with green Robusta extract, 3 - supplemented with green Arabica extract, 4 - supplemented with roasted Robusta extract, 5 - supplemented with green Arabica extract, 6 - with no supplement (control).

coffee extracts are applicable to fats with different degrees of unsaturation like sunflower oil and pork lard. Because of the very high content of polyphenols in crude extracts from green coffee beans, in particular Robusta, the production and application of inexpensive and efficient antioxidant preparations, that can be used to stabilize fats, appears to be both economically effective and beneficial for the health of consumers.

\section{ACKNOWLEDGMENTS}

The authors thank the Polish Ministry of Education and Science for its financial support (Grant No 2 P06T 06029 ) of this research.

\section{REFERENCES}

Albi T, Lanzon A, Guinda A, Leon M, Perez-Camino MC. 1997. Microwave and conventional heating effects on thermoxidative degradation of edible fats. J. Agric. Food Chem. 45, 3795-3798.

Anwar F, Jamil A, Iqbal S, Sheikh MA. 2006. Antioxidant activity of various plant extracts under ambient and accelerated storage of sunflower oil. Grasas y Aceites 57,189-197. 
Bandonienè D, Pukalskas A, Venskutonis PR, Gruzdien D. 2000. Preliminary screening of antioxidant activity of some plant extracts in rapeseed oil. Food Res. Int. 33, 785-791.

Besbes S, Blecker C, Deroanne C, Lognay G, Drira $\mathrm{NE}$, Attia H. 2005. Heating effects on some quality characteristics of date seed oil. Food Chem. 91, 469476.

Budryn G, Nebesny E, Podsędek A, Żyżelewicz D, Materska M, Jankowski S, Janda B. 2009. Effect of different extraction methods on the recovery of chlorogenic acids, caffeine and Maillard reaction products in coffee bean. Eur. Food Res. Technol. 228, 913-922.

Calligaris S, Arrighetti G, Barba L, Nicoli MC. 2008. Phase transition of sunflower oil as affected by the oxidation level. J. Am. Oil Chem. Soc. 85, 591-598.

Campos R, Narine SS, Mrangoni AG. 2002. Effect of cooling rate on the structure and mechanical properties of milk fat and lard. Food Res. Int. 35, 971-981.

Chiavaro E, Vittadini E, Rodriguez-Estrada MT, Cerretani L, Bonoli M, Bendini A, Lercker G. 2007. Monovarietal extra virgin olive oils: correlation between thermal properties and chemical composition. J. Agric. Food Chem. 55, 10779-10786.

Daglia M, Papetti A, Gregotti C, Berte F, Gazzani G. 2000. In vitro antioxidant and ex vivo protective activities of green and roasted coffee. J. Agric. Food Chem. 48, 1449-1454.

Gloria H, Aguilera JM. 1998. Assessment of the quality of heated oils by differential scanning calorimetry. $J$. Agric. Food Chem. 46, 1363-1368.

Guillen MD, Cabo N. 2002. Fourier transform infrared spectra data versus peroxide and anisidine values to determine oxidative stability of edible oils. Food Chem. 77, 503-510.

Iqbal S, Bhanger MI. 2007. Stabilization of sunflower oil by garlic extract during accelerated storage. Food Chem. 100, 246-254.

Irwandi J, Che Man YB, Kitts DD, Bakar J, Jinap S. 2000. Synergies between plant antioxidant blends in preventing peroxidation reactions in model and food oil system. J. Am. Oil Chem. Soc. 77, 945-950.

Lakenbrink C, Lapczynski S, Maiwald B, Engelhardt UH. 2000. Flavonoids and other polyphenols in consumer brews of tea and other caffeinated beverages. J. Agric. Food Chem. 48, 2848-2852.

Lopez-Galilea I, Andueza S, Leonardo I, Paz de Pena M, Cid C. 2006. Influence of torrefacto roast on antioxidant and pro-oxidant activity of coffee. Food Chem. 94, 75-80.
Luzia MR, da Paixão KCC, Marcilio R, Trugo LC, Quinteiro LMC, de Maria CAB. 1997. Effect of 5 -caffeoylquinic acid on soybean oil oxidative stability. Int. J. Food Sci. Technol. 32, 15-19.

Nissen LR, Byrne DV, Bertelsen G, Skibsted LH. 2004. The antioxidative activity of plant extracts in cooked pork patties as evaluated by descriptive sensory profiling and chemical analysis. Meat Sci. 68, 485495.

Renuka Devi R, Jayalekshmy A, Arumughan C. 2007. Antioxidant efficacy of phytochemical extracts from defatted rice bran in the bulk oil system. Food Chem. 104, 658-664.

Schwarz K, Bertelsen G, Nissen LR, Gardner PT, Heinonen MI, Hopia A, Huynh-Ba T, Lambelet P, McPhail D, Skibsted LH, Tijburg L. 2001. Investigation of plant extracts for the protection of processed foods against lipid oxidation. Comparison of antioxidant assays based on radical scavenging, lipid oxidation and analysis of the principal antioxidant compounds. Eur. Food Res. Technol. 212, 319-328.

Shishikura Y, Khokhar S, Murray BS. 2006. Effects of tea polyphenols on emulsification of olive oil in a small intestine model system. J. Agric. Food Chem. 54, 1906-1913.

Sikwese FE, Duodu KG. 2007. Antioxidant effect of a crude phenolic extract from sorghum bran in sunflower oil in the presence of ferric ions. Food Chem. 104, 324-331.

Suja KP, Abraham JT, Thamizh SN, Jayalekshmy A, Arumughan C. 2004. Antioxidant efficacy of sesame cake extract in vegetable oil protection. Food Chem. 84, 393-400.

Tan CP, Che Man YB. 1999a. Differential scanning calorimetric analysis for monitoring the oxidation of heated oils. Food Chem. 67, 177-184.

Tan CP, Che Man YB. 1999b. Quantitative differential scanning calorimetric analysis for determining total polar compounds in heated oils. J. Am. Oil Chem. Soc. 76, 1047-1057.

Tan CP, Che Man YB, Jinap S, Yusoff MSA. 2002. Effect of microwave heating on the quality characteristics and thermal properties of RBD palm olein. Inn. Food Sci. Emerg. Technol. 3, 157-163.

Vittadini E, Lee JH, Frega NG, Min DB, Vodovotz Y. 2003. DSC determination of the thermally oxidized olive oil. J. Am. Oil Chem. Soc. 80, 533-537. 